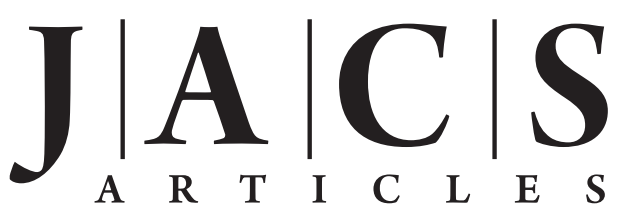

Published on Web 08/28/2009

\title{
Proton-Coupled Oxygen Reduction at Liquid-Liquid Interfaces Catalyzed by Cobalt Porphine
}

\author{
Imren Hatay, ${ }^{\dagger, \ddagger}$ Bin Su, ${ }^{\dagger}$ Fei Li, ${ }^{\dagger}$ Manuel Alejandro Méndez, ${ }^{\dagger}$ Tony Khoury, ${ }^{\S}$ \\ Claude P. Gros, ${ }^{\S}$ Jean-Michel Barbe, ${ }^{\S}$ Mustafa Ersoz, ${ }^{\ddagger}$ Zdenek Samec, ${ }^{\#}$ and \\ Hubert H. Girault ${ }^{\star}, \dagger$ \\ Laboratoire d'Electrochimie Physique et Analytique, Ecole Polytechnique Fédérale de Lausanne, \\ Station 6, CH-1015 Lausanne, Switzerland, Department of Chemistry, Selcuk University, \\ 42031 Konya, Turkey, Institut de Chimie Moléculaire de l'Université de Bourgogne, ICMUB \\ (UMR 5260), 21078 Dijon cedex, France, and J. Heyrovsky Institute of Physical Chemistry, \\ Academy of Sciences of the Czech Republic, Dolejskova 3, 18223 Prague 8, Czech Republic
}

Received June 5, 2009; E-mail: hubert.girault@epfl.ch

\begin{abstract}
Cobalt porphine (CoP) dissolved in the organic phase of a biphasic system is used to catalyze $\mathrm{O}_{2}$ reduction by an electron donor, ferrocene $(\mathrm{Fc})$. Using voltammetry at the interface between two immiscible electrolyte solutions (ITIES), it is possible to drive this catalytic reduction at the interface as a function of the applied potential difference, where aqueous protons and organic electron donors combine to reduce $\mathrm{O}_{2}$. The current signal observed corresponds to a proton-coupled electron transfer (PCET) reaction, as no current and no reaction can be observed in the absence of either the aqueous acid, CoP, Fc, or $\mathrm{O}_{2}$.
\end{abstract}

\section{Introduction}

Oxygen reduction catalyzed by porphyrins is of great interest in fields as diverse as biology, photosynthesis, and electrocatalysis. ${ }^{1,2}$ In nature, oxygen reduction occurs at soft interfaces, namely biomembranes that provide both a physical separation of the reactants and products, and an electrochemical driving force resulting from the membrane electrical potential difference. Electrochemistry at liquid-liquid interfaces is a new type of bioinspired electrochemistry. Indeed, the interface between two immiscible electrolyte solutions (ITIES) provides a physical separation of the reactants and products, and the polarization of this soft interface also allows an electrochemical control for different charge transfer reactions such as ion transfer, assisted ion transfer (e.g. acid-base reactions involving an interfacial protonation), and heterogeneous electron transfer reactions between a hydrophilic and a lipophilic redox couple. ${ }^{3-7}$ Here, we demonstrate that voltammetry is a very powerful tool to

\footnotetext{
† Ecole Polytechnique Fédérale de Lausanne.

$\doteqdot$ Selcuk University.

§ Université de Bourgogne.

\# Academy of Sciences of the Czech Republic.

(1) Boulatov, R. In N4-Macrocyclic Metal Complexes; Zagal, J. H., Bedioui, F., Dodelet, J.-P., Eds.; Springer: New York, 2006; Vol. 1, pp $1-36$.

(2) Zagal, J. H.; Paez, M. A.; Silva, J. F. In N4-Macrocyclic Metal Complexes; Zagal, J. H., Bedioui, F., Dodelet, J.-P., Eds.; Springer: New York, 2006; Vol. 2, pp 41-75.

(3) Girault, H. H. In Modern Aspects of Electrochemistry; Bockris, J. O. M., Conway, B. E., White, R. E., Eds.; Springer-Verlag: New York, 1993; Vol. 25g, pp 1-62.

(4) Reymond, F.; Fermin, D.; Lee, H. J.; Girault, H. H. Electrochim. Acta 2000, 45, 2647-2662.

(5) Volkov, A. G., Deamer, D. W., Eds. In Liquid-Liquid Interfaces: Theory and Methods; CRC Press: Boca Raton, 1996.

(6) Volkov, A. G.; Deamer, D. W.; Tanelian, D. L.; Markin, V. A. S. Liquid Interfaces in Chemistry and Biology; Wiley-VCH: New York, 1998.

(7) Samec, Z. Chem. Rev. 1988, 88, 617-32.
}

study proton-coupled electron transfer (PCET) reactions at soft interfaces and to provide evidence of interfacial electrocatalytic reactions, i.e. catalytic reactions that are dependent on the soft interface polarization.

In classical molecular electrocatalysis, porphyrin catalysts are usually deposited on solid electrodes, and their catalytic activity is observed as a shift of the reduction current to higher electrode potential values. A variety of porphyrins have been studied with this voltammetric methodology. ${ }^{2,8-11}$ In this case, both the structure of the adsorbed porphyrin layer and that of the electrode surface have a significant impact on the catalytic reaction mechanisms. For example, cobalt(II) porphine (CoP) and other cobalt porphyrins such as $[2,3,7,8,12,13,17,18$ octaethyl-21H,23H-porphyrin]cobalt(II) (CoOEP) have been shown to catalyze a four-electron reduction of $\mathrm{O}_{2}$ to $\mathrm{H}_{2} \mathrm{O}$ when being adsorbed on graphite electrodes, ${ }^{12}$ and to catalyze mainly a two-electron reduction of $\mathrm{O}_{2}$ to yield hydrogen peroxide $\left(\mathrm{H}_{2} \mathrm{O}_{2}\right)$ when being deposited onto gold electrodes. ${ }^{13} \mathrm{O}_{2}$ reduction both to $\mathrm{H}_{2} \mathrm{O}_{2}$ and to $\mathrm{H}_{2} \mathrm{O}$ are proton-coupled electron transfer (PCET) reactions, in which proton transfer and electron transfer are tightly coupled. Voltammetry measurements on solid electrodes record the electron transfer step of the catalytic cycle and have been widely used to elucidate PCET reaction mech-

(8) Anson, F. C.; Shi, C.; Steiger, B. Acc. Chem. Res. 1997, 30, 437444.

(9) Collman, J. P.; Marrocco, M.; Denisevich, P.; Koval, C.; Anson, F. C. J. Electroanal. Chem. Interfacial Electrochem. 1979, 101, $117-22$.

(10) Durand, R. R., Jr.; Anson, F. C. J. Electroanal. Chem. Interfacial Electrochem. 1982, 134, 273-89.

(11) Shi, C.; Steiger, B.; Anson, F. C. Pure Appl. Chem. 1995, 67, 31922.

(12) Shi, C.; Steiger, B.; Yuasa, M.; Anson, F. C. Inorg. Chem. 1997, 36, 4294-4295.

(13) Yoshimoto, S.; Inukai, J.; Tada, A.; Abe, T.; Morimoto, T.; Osuka, A.; Furuta, H.; Itaya, K. J. Phys. Chem. B 2004, 108, 1948-1954. 
anisms as recently reviewed by Huynh and Meyer and Costentin. ${ }^{14,15}$

The interface between two immiscible electrolyte solutions is formed between two solvents of a low mutual miscibility, such as water and 1,2-dichloroethane (DCE), each containing an electrolyte. An ITIES can be polarized with the formation of two back-to-back Gouy-Chapman diffuse layers, and it is possible to use classical methodologies to study charge transfer reactions, as well as adsorption phenomena. This type of electrochemistry without a solid working electrode provides a suitable model for investigating heterogeneous processes occurring in biological systems, which are often PCET reactions such as the proton-coupled oxygen reduction reactions within aerobic living organisms. Oxygen reduction at the ITIES has been studied by using various lipophilic electron donors, decamethylferrocene (DMFc), ${ }^{16-21}$ reduced flavin mononucleotide (FMN) ${ }^{22}$ tetrachlorohydroquinone $\left(\mathrm{CQH}_{2}\right)^{23}$ and fullerene monoanion $\left(\mathrm{C}_{60}{ }^{-}\right) \cdot{ }^{24}$ In the case of DMFc, the oxygen reduction produces $\mathrm{H}_{2} \mathrm{O}_{2}$, as evidenced by two-phase reactions ${ }^{19}$ and in situ detection of $\mathrm{H}_{2} \mathrm{O}_{2}$ using scanning electrochemical microscopy.$^{20}$ Furthermore, the catalytic effect of various porphyrin compounds including cobalt tetraphenylporphyrin, ${ }^{18,21}$ as well as electrodeposited platinum particles ${ }^{17}$ on the oxygen reduction by DMFc at the water-DCE interface has also been investigated.

Herein, we report that cobalt porphine $(\mathrm{CoP})$ catalyzes the reduction of $\mathrm{O}_{2}$ in biphasic systems where the aqueous phase is acidic and where the organic phase contains electron donors. In particular, we show by voltammetry at ITIES that this interfacial catalytic process occurs through a proton-coupled electron transfer (PCET) reaction that depends on the interfacial polarization, i.e. on the potential difference applied between the two phases. Indeed, no reaction takes place in the absence of either $\mathrm{CoP}$, ferrocene $(\mathrm{Fc})$ or $\mathrm{O}_{2}$. In this biphasic system, the reactants are separated by the interface with the protons in the aqueous phase, the catalyst and the electron donor in the organic phase. Voltammetry at ITIES records the current, i.e. the passage of charges through the interface. In the case of the interfacial catalytic reduction of $\mathrm{O}_{2}$, the current records the transport of $\mathrm{H}^{+}$from the aqueous phase to the interfacial reaction site. This is the main difference with voltammetry at solid electrodes that only records electron transfer steps. Furthermore, the oxidation product of ferrocene, namely ferrocenium, does not cross the interface in the same potential

(14) Huynh, M. H. V.; Meyer, T. J. Chem. Rev. 2007, 107, 5004-5064.

(15) Costentin, C. Chem. Rev. 2008, 108, 2145-2179.

(16) Cunnane, V. J.; Geblewicz, G.; Schifferin, D. J. Electrochim. Acta 1995, 40, 3005-14.

(17) Trojanek, A.; Langmaier, J.; Samec, Z. Electrochem. Commun. 2006, $8,475-481$.

(18) Trojanek, A.; Marecek, V.; Janchenova, H.; Samec, Z. Electrochem. Commun. 2007, 9, 2185-2190.

(19) Su, B.; Nia, R. P.; Li, F.; Hojeij, M.; Prudent, M.; Corminboeuf, C.; Samec, Z.; Girault, H. H. Angew. Chem. Int. Ed. 2008, 47, 46754678.

(20) Li, F.; Su, B.; Salazar, F. C.; Nia, R. P.; Girault, H. H. Electrochem. Commun. 2009, 11, 473-476.

(21) Partovi-Nia, R.; Su, B.; Li, F.; Gros, C. P.; Barbe, J.-M.; Samec, Z.; Girault, H. H. Chem.-Eur. J. 2009, 15, 2335-2340.

(22) Suzuki, M.; Matsui, M.; Kihara, S. J. Electroanal. Chem. 1997, 438, 147-151.

(23) Ohde, H.; Maeda, K.; Yoshida, Y.; Kihara, S. J. Electroanal. Chem. 2000, 483, 108-116.

(24) Liljeroth, P.; Quinn, B. M.; Kontturi, K. Langmuir 2003, 19, 51215127.
Scheme 1. Molecular Structure of CoP

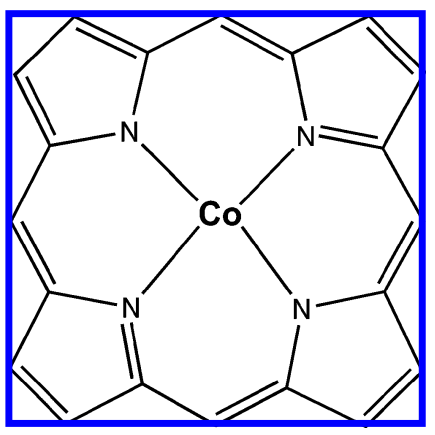

Scheme 2. Three-Compartment Glass Cell for Liquid-Liquid Electrochemistry

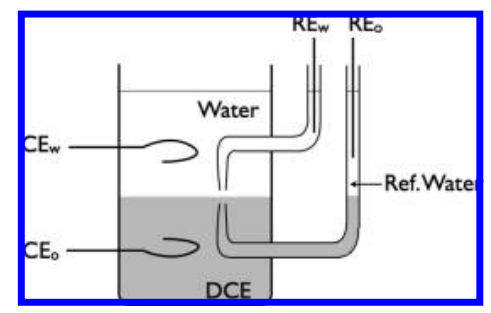

range as that of the PCET reaction and the two processes can be observed.

\section{Experimental Section}

Chemicals and Reagents. All solvents and chemicals were used as received without further purification. Ferrocene (Fc, 98\%), 1,1'dimethylferrocene (DFc, 97\%), ferrocene carboxaldehyde (FcCA, $98 \%$ ), and lithium tetrakis(pentafluorophenyl)borate diethyl etherate (LiTB) were purchased from Aldrich. Lithium chloride anhydrous ( $\mathrm{LiCl}, \geq 99 \%)$, hydrochloric acid $(\mathrm{HCl}, 37 \%), 1,2$-dichloroethane (DCE, $\geq 99.8 \%$ ), sodium iodide (NaI, $>99.5 \%$ ), tetraethylammonium chloride (TEACl, $\geq 98 \%$ ), and bis(triphenylphosphoranylidene)ammonium chloride (BACl, $\geq 98 \%$ ) were obtained from Fluka. Hydrogen peroxide $\left(\mathrm{H}_{2} \mathrm{O}_{2}, 30 \%\right)$ was ordered from Reactolab SA. Bis(triphenylphosphoranylidene)ammonium tetrakis(pentafluorophenyl)borate (BATB) was prepared by metathesis of $1: 1$ mixtures of $\mathrm{BACl}$ and $\mathrm{LiTB}$ in a methanol/water mixture $(\mathrm{V}: \mathrm{V}=2: 1)$, followed by recrystallization from acetone. ${ }^{25}$ All the aqueous solutions were prepared with ultra pure water $\left(18.2 \mathrm{M} \Omega \mathrm{cm}^{-1}\right)$. The $\mathrm{pH}$ of the acidic aqueous solutions was adjusted by addition of $\mathrm{HCl}$. The synthesis of CoP is detailed in the Supporting Information, and its molecular structure is illustrated in Scheme 1.

Voltammetric Measurements. Voltammetry measurements at the water-DCE interface were performed in a four-electrode configuration with two reference electrodes to polarize the interface and two counter electrodes to provide the current. A commercial potentiostat (PGSTAT 30, Eco-Chemie, Netherlands) or a custombuilt system connected to a Stanford Research System DS335 synthesized function generator was used. A three-compartment glass cell featuring a cylindrical vessel was used, where the water-DCE interface with a geometric area of $1.53 \mathrm{~cm}^{2}$ was formed as illustrated in Scheme 2. Two platinum counter electrodes were positioned in the aqueous and DCE phases, respectively, to supply the current flow. The external potential was applied by means of two silver/ silver chloride $(\mathrm{Ag} / \mathrm{AgCl})$ reference electrodes, which were connected to the aqueous and DCE phases, respectively, by means of a Luggin capillary. The electrochemical cell composition is schematically illustrated in Scheme 3 . The Galvani potential difference $\left(\Delta_{o}^{\mathrm{w}} \phi\right)$ was estimated by taking the formal ion transfer

(25) Su, B.; Abid, J.-P.; Fermin, D. J.; Girault, H. H.; Hoffmannova, H.; Krtil, P.; Samec, Z. J. Am. Chem. Soc. 2004, 126, 915-919. 
Scheme 3. Composition of the Electrochemical Cell

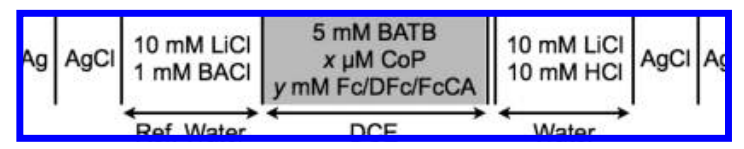

potential of tetraethylammonium cation $\left(\mathrm{TEA}^{+}\right)$as $0.019 \mathrm{~V} .^{26}$ The cyclic voltammograms recorded during the second potential cycling scan were showed, unless otherwise specified. A scan rate of 0.05 $\mathrm{V} \mathrm{s}^{-1}$ was used.

Two-Phase Reactions Controlled by a Common Ion. Twophase reactions were performed in small glass flasks, to which 2 $\mathrm{mL}$ of DCE solution containing reactants $(\mathrm{Fc}, \mathrm{CoP})$ was added first, followed by the addition of $2 \mathrm{~mL}$ of an aqueous solution containing $10 \mathrm{mM} \mathrm{HCl}$. The salts of the common ion $\left(\mathrm{TB}^{-}\right), \mathrm{LiTB}$, and BATB, were added in the same concentration of $5 \mathrm{mM}$ to the aqueous and DCE phases, respectively. After stirring and further waiting for the clear separation of two phases, the aqueous and organic solutions were isolated from each other. The organic phase was directly subjected to UV-visible spectroscopic measurements, while the aqueous phase was first treated by excess $\mathrm{NaI}$ (equivalent to 0.1 $\mathrm{M})$ prior to the UV-visible spectroscopic measurements. The UV-visible spectroscopic measurements were performed on an Ocean Optical CHEM2000 spectrophotometer. The experiments under anaerobic conditions were carried out in a glovebox purged by nitrogen. All the experiments were performed at an ambient temperature $\left(23 \pm 2{ }^{\circ} \mathrm{C}\right)$ with air-saturated solutions unless specified otherwise.

\section{Results and Discussion}

Proton-Coupled Oxygen Reduction. Figure 1a compares the first scan of four cyclic voltammograms obtained by polarizing the water-DCE interface from -0.25 to $0.4 \mathrm{~V}$. The supporting electrolytes, namely $\mathrm{LiCl}$ and BATB determine the size of the potential window. $\mathrm{BA}^{+}$and $\mathrm{TB}^{-}$being very lipophilic ions, the

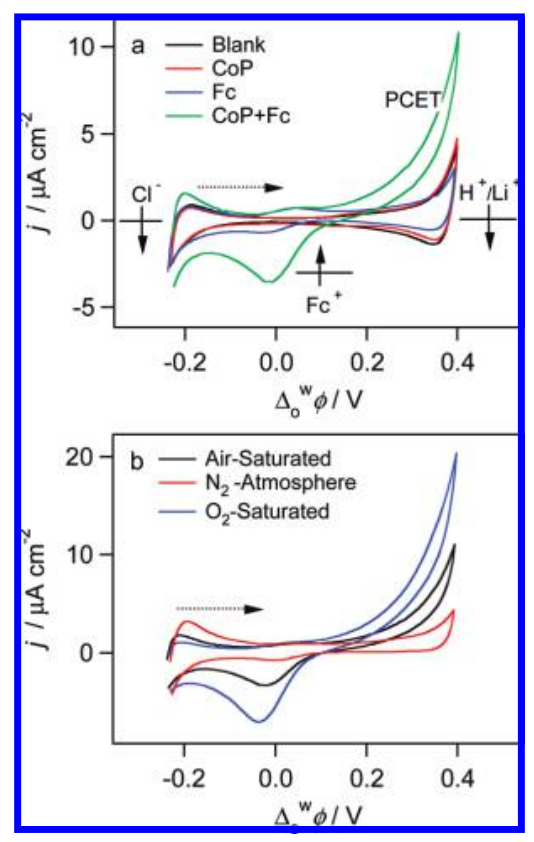

Figure 1. (a) Cyclic voltammetry obtained at a water-DCE interface with the cell illustrated in Scheme 3: $x=0$ and $y=0$ (black), $x=50$ and $y=$ 0 (red), $x=0$ and $y=5$ (blue), and $x=50$ and $y=5$ (green). (b) Same with $x=50$ and $y=5$ under air-saturated (black), anaerobic (red), and oxygen-saturated (blue) conditions. The dotted arrows in the figure direct the forward scan. The vertical and horizontal axes respectively represent the electric current density flow across the water-DCE interface and the Galvani potential difference across the interface.
Table 1. Calculated Equilibrium Concentrations after Contact with $5 \mathrm{mM}$ BATB in DCE with $10 \mathrm{mM} \mathrm{HCl}$ and $5 \mathrm{mM}$ LiTB in Water ${ }^{a}$

\begin{tabular}{lcclccc}
\hline & $C_{\mathrm{Fc}_{\mathrm{c}}}+/ \mathrm{mM}$ & $c_{\mathrm{H}}+/ \mathrm{mM}$ & \multicolumn{1}{c}{$c_{\mathrm{BA}}+/ \mathrm{mM}$} & $c_{\mathrm{TB}}-/ \mathrm{mM}$ & $C_{\mathrm{Li}}+/ \mathrm{mM}$ & \multicolumn{1}{c}{$c_{\mathrm{Cl}}-/ \mathrm{mM}$} \\
\hline water & 0 & 5.81 & $2.46 \times 10^{-19}$ & 0.14 & 4.34 & 10.00 \\
DCE & 0 & 4.19 & 5.00 & 9.86 & 0.66 & $7.50 \times 10^{-18}$
\end{tabular}

${ }^{a}$ The Galvani potential difference across the water-DCE interface calculated is approximately $0.54 \mathrm{~V}$.

potential window is limited by the transfer of $\mathrm{Cl}^{-}$at negative potentials and by the transfer of $\mathrm{H}^{+}$at positive potentials. Compared to the background voltammetric response, the presence of either CoP or Fc only did not introduce any significant changes. Note that in the latter case a small wave around $0 \mathrm{~V}$ corresponds to the transfer of some traces of ferrocenium $\left(\mathrm{Fc}^{+}\right)$ present in the system. ${ }^{16}$ In contrast, when CoP and Fc were both present, a large irreversible positive current wave was observed at positive potentials, i.e. a wave without a signal on the return scan. However, on this return scan a current wave for $\mathrm{Fc}^{+}$transfer can be clearly observed, indicating that $\mathrm{Fc}^{+}$ was produced when the interface is positively polarized. Upon repetitive cycling, steady increase of this $\mathrm{Fc}^{+}$ion transfer wave indicates that more ferrocenium ions are being produced. Figure $1 \mathrm{~b}$ clearly shows that the irreversible current wave disappears under anaerobic conditions and is enhanced under oxygensaturated conditions, thereby producing more $\mathrm{Fc}^{+}$. This voltammetric data undoubtedly shows that this irreversible wave results from the combined presence of protons, $\mathrm{CoP}, \mathrm{Fc}$, and $\mathrm{O}_{2}$.

In the following, two-phase reactions were performed. Typically, a DCE solution containing $5 \mathrm{mM}$ BATB and $5 \mathrm{mM}$ $\mathrm{Fc} / 50 \mu \mathrm{M}$ CoP was put in contact with an aqueous solution containing $5 \mathrm{mM}$ LiTB and $10 \mathrm{mM} \mathrm{HCl}$ in a small flask. In this case, the Galvani potential difference between the two phases resulting from the distribution of all the ions is dominated by the partition of the common ion, here $\mathrm{TB}^{-}$anion. With such a choice of electrolyte, this distribution of Galvani potential difference can be calculated knowing the respective Gibbs energy of transfer of the different ionic species and is found to be approximately $0.54 \mathrm{~V}$ (Table 1, and Supporting Information). At equilibrium in the absence of ferrocene, the acid HTB is extracted in the organic phase at a concentration of $4.19 \mathrm{mM}$ (Table 1). After stirring the reaction flask for a couple of seconds, the two phases were separated from each other and were analyzed. As shown in Figures 2a, when only Fc was present (flask 1), the color and UV-visible spectrum of DCE phase did not change, indicating that no reaction took place (Note that it takes many hours to detect $\mathrm{Fc}^{+}$in this case as the direct oxidation of ferrocene by oxygen is a very slow process). When only CoP was added (flask 3), the DCE phase kept its pink color, and a red shift of both Soret and Q bands were observed in its UV-visible spectrum (Figure 3a), which is ascribed to the oxygenation of $\mathrm{Co}^{\mathrm{II}} \mathrm{P}$ by the formation of superoxide adduct considered formally as $\left(\mathrm{Co}^{\mathrm{III}}-\mathrm{O}_{2}\right) \mathrm{P} .{ }^{27} \mathrm{In}$ contrast, in the presence of both Fc and CoP (flask 2) the color of DCE solution changed instantaneously upon contact with the aqueous solution, and the final color indicates a mixture of $\mathrm{Fc}^{+}$ and $\mathrm{CoP}$. In the UV-visible spectrum (Figure 3a), a strong absorption band at $620 \mathrm{~nm}$ due to $\mathrm{Fc}^{+}$was observed, ${ }^{21}$ the intensity of which suggests that all $\mathrm{Fc}$ was oxidized to $\mathrm{Fc}^{+}$.

(26) Wandlowski, T.; Marecek, V.; Samec, Z. Electrochim. Acta 1990, 35, 1173-5.

(27) Collman, J. P.; Brauman, J. I.; Doxsee, K. M.; Halbert, T. R.; Hayes, S. E.; Suslick, K. S. J. Am. Chem. Soc. 1978, 100, 2761-6. 


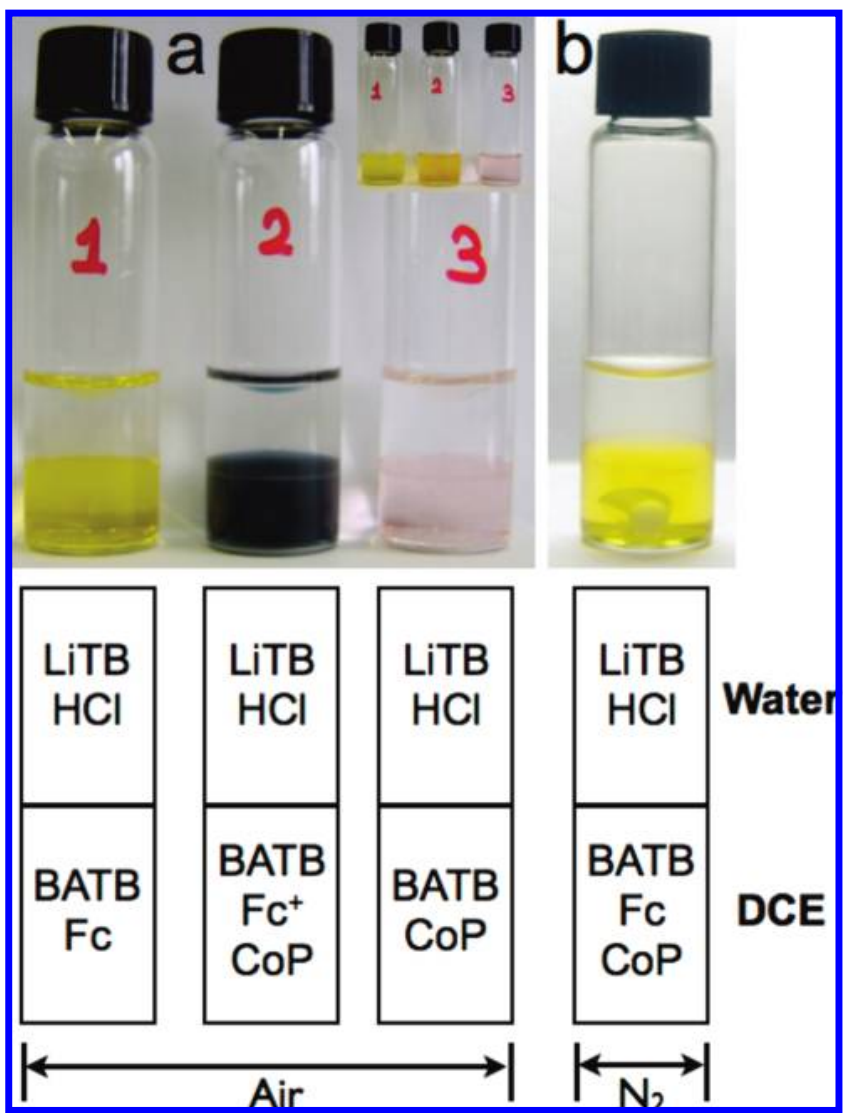

Figure 2. (a) Photographic illustrations of two-phase reactions controlled by $\mathrm{TB}^{-}$partition after shaking a couple of seconds: the top aqueous phase containing $5 \mathrm{mM} \mathrm{LiTB}+10 \mathrm{mM} \mathrm{HCl}$ was the same for all three flasks; the bottom DCE phase contained $5 \mathrm{mM} \mathrm{Fc}, 5 \mathrm{mM} \mathrm{Fc}+50 \mu \mathrm{M} \mathrm{CoP}$, and $50 \mu \mathrm{M}$ CoP in flask 1,2 , and 3, respectively; the inset shows the flasks before adding the top aqueous solution. (b) Two-phase reaction under anaerobic conditions with other conditions the same as flask 2 in Figure 2a. The notations under the figure illustrate the solution composition of each flask.

By treating the aqueous phases with sodium iodide $(\mathrm{NaI})$, hydrogen peroxide $\left(\mathrm{H}_{2} \mathrm{O}_{2}\right)$ was detected only in the aqueous phase of flask $2 .{ }^{19} \mathrm{H}_{2} \mathrm{O}_{2}$ oxidizes iodide to triiodide, displaying two absorption bands at 286 and $352 \mathrm{~nm}$ as shown in Figure 3b. However, the $\mathrm{H}_{2} \mathrm{O}_{2}$ detected in water was $0.445 \mathrm{mM}$, corresponding to a yield of $18 \%$ if considering a two-electron reduction (Assuming the concentration of $\mathrm{O}_{2}$ in this open experimental system and that of proton are in excess, the theoretical yield of $\mathrm{H}_{2} \mathrm{O}_{2}$ amounts to $2.5 \mathrm{mM}$ ). For comparison, the yield of $\mathrm{H}_{2} \mathrm{O}_{2}$ production in similar experiments using decamethylferrocene as a donor in the absence of catalysts was about $40 \% .{ }^{19}$ Moreover, the percentage of $\mathrm{H}_{2} \mathrm{O}_{2}$ produced here decreases with increasing the molar ratio of $\mathrm{Fc}$ to $\mathrm{H}^{+}$and becomes negligible when this ratio exceeds 1 . This suggests that the reduction of $\mathrm{O}_{2}$ is either a direct four-electron reduction of $\mathrm{O}_{2}$ to $\mathrm{H}_{2} \mathrm{O}$ catalyzed by $\mathrm{CoP}$ or that $\mathrm{H}_{2} \mathrm{O}_{2}$ formed via a twoelectron reduction pathway is further reduced by Fc. A fourelectron reduction pathway has been observed on graphite electrodes for $\mathrm{CoP}^{12}$ and is due to the formation of $\mathrm{CoP}$ dimers which function like biscobalt bisporphyrins. It is well-known that some biscobalt bisporphyrins with an optimal molecular geometry can catalyze four-electron reduction of $\mathrm{O}_{2}$ to $\mathrm{H}_{2} \mathrm{O}^{28}$ Here, CoP may form dimers at the liquid-liquid interface in a face-to-face geometry or may form one-dimensional polymers, which are currently being investigated by interface-sensitive

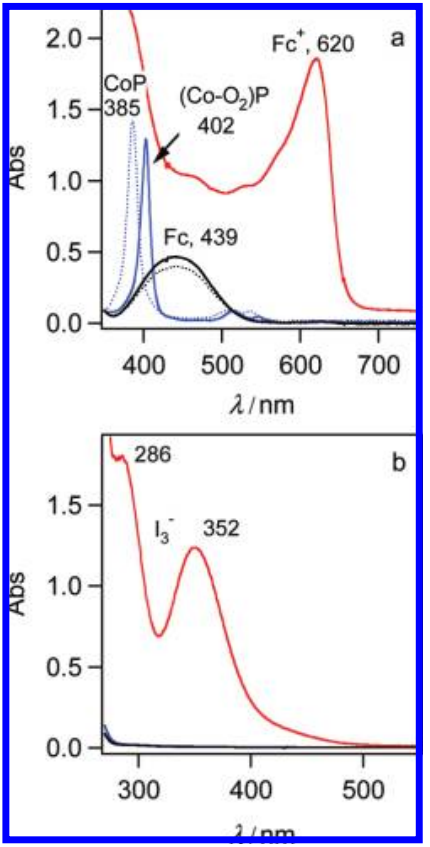

Figure 3. (a) UV-visible spectra of the DCE phases separated from the flask 1 (black), flask 2 (red), and flask 3 (blue) after the two-phase reaction illustrated in Figure 2a; that of freshly prepared $5 \mathrm{mM} \mathrm{Fc} \mathrm{(dotted} \mathrm{black)}$ and $50 \mu \mathrm{M} \mathrm{CoP}$ (dotted blue) are also given for comparison. (b) UV-visible spectra of the aqueous phases separated from the flask 1 (black), flask 2 (red), and flask 3 (blue) after being treated with excess $\mathrm{NaI}$ for $30 \mathrm{~min}$. The solutions were diluted ten times prior to measurements.

spectroscopy in our lab. Regarding the further reduction of $\mathrm{H}_{2} \mathrm{O}_{2}$ by $\mathrm{Fc}$, it can occur either heterogeneously or homogenously. To elucidate this point, a comparative test (Supporting Information) was therefore performed with the Galvani potential difference controlled either by the distribution of the common ion $\mathrm{TMA}^{+}$or that of $\mathrm{TB}^{-}$, approximately at 0.16 and $0.54 \mathrm{~V}$, respectively, as shown in Tables 1 and 3. In the former case, protons having a standard ion transfer potential of $0.55 \mathrm{~V}^{26}$ are mainly confined to the aqueous phase, and the partition of neutral $\mathrm{H}_{2} \mathrm{O}_{2}$ from water to DCE also occurs. ${ }^{29}$ However, no oxidation of $\mathrm{Fc}$ was observed (Supporting Information, Figure S-1), which suggests that the heterogeneous reduction of $\mathrm{H}_{2} \mathrm{O}_{2}$ located in acidic water by Fc in DCE does not occur even if it is thermodynamically favorable. It also proves that without the presence of protons in the organic phase $\mathrm{Fc}$ does not react with $\mathrm{H}_{2} \mathrm{O}_{2}$ in DCE. In contrast, when $4.19 \mathrm{mM}$ HTB is available in DCE when using $\mathrm{TB}^{-}$as the common ion (Table 1), an immediate oxidation of $\mathrm{Fc}$ is observed. Therefore, it can be concluded that the reaction of $\mathrm{Fc}$ with the formed $\mathrm{H}_{2} \mathrm{O}_{2}$ occurs homogenously in DCE in the presence of organic protons. Indeed, thermodynamic calculations show that $\mathrm{H}_{2} \mathrm{O}_{2}$ in DCE is much more oxidizing than in water as given in Table 4 .

The above two possibilities, either two- or four-electron reduction, for $\mathrm{H}_{2} \mathrm{O}$ production are however difficult to differentiate in the present biphasic system. Nevertheless, a control experiment under anaerobic conditions showed that no reaction took place (neither $\mathrm{Fc}^{+}$nor $\mathrm{H}_{2} \mathrm{O}_{2}$ was detected as shown in Figure $2 \mathrm{~b}$ ), which undoubtedly confirms the occurrence of an oxygen reduction reaction catalyzed by $\mathrm{CoP}$ in this biphasic

(28) Collman, J. P.; Boulatov, R.; Sunderland, C. J. In Porphyrin Handbook; Kadish, K. M., Smith, K. M., Guilard, R., Eds.; Academic Press: New York, 2003; Vol. 11, pp 1-49.

(29) Trojanek, A.; Samec, Z. Private communications. 
Table 2. Calculated Equilibrium Concentrations after Contacting $5 \mathrm{mM} \mathrm{Fc}$ and $5 \mathrm{mM}$ BATB in DCE with $10 \mathrm{mM} \mathrm{HCl}$ and 5 mM LiTB in Water $^{a}$

\begin{tabular}{|c|c|c|c|c|c|c|}
\hline & $\mathrm{C}_{\mathrm{Fc}}+/ \mathrm{mM}$ & $\mathrm{CH}^{+} / \mathrm{mM}$ & $c_{\mathrm{BA}}+/ \mathrm{mM}$ & $c_{\mathrm{TB}}-/ \mathrm{mM}$ & $\mathrm{CLi}_{\mathrm{i}}+/ \mathrm{mM}$ & $c_{\mathrm{Cl}}-/ \mathrm{mM}$ \\
\hline water & $1.25 \times 10^{-4}$ & 5.00 & $8.89 \times 10^{-15}$ & $4.06 \times 10^{-6}$ & 5.00 & 10.00 \\
\hline DCE & 5.00 & $9.98 \times 10^{-5}$ & 5.00 & 10.00 & $2.10 \times 10^{-5}$ & $2.72 \times 10^{-13}$ \\
\hline
\end{tabular}

${ }^{a}$ The Galvani potential difference across the water-DCE interface calculated is approximately $0.27 \mathrm{~V}$.

system. Moreover, both voltammetric and two-phase reaction data (Figures 1 and 2) clearly show that this catalytic oxygen reduction reaction requires the concomitant presence of $\mathrm{H}^{+}, \mathrm{CoP}$, $\mathrm{Fc}$, and $\mathrm{O}_{2}$ at positive Galvani potential differences fixed either with a potentiostat (Figure 1) or chemically by a salt distribution (Figure 2). A control cyclic voltammetry measurement also proved that in the available potential window no reaction takes place between $\mathrm{Fc}$ in DCE and $\mathrm{H}_{2} \mathrm{O}_{2}$ in acidic aqueous phase (Supporting Information, Figure S-2). Therefore, the irreversible current wave in Figure 1 corresponds to an interfacial protoncoupled oxygen reduction process, where the electron and proton transfer occur concomitantly. As reported previously by Fukuzumi et al. in a homogeneous organic system, $\mathrm{O}_{2}$ reduction by $\mathrm{Fc}$ in the presence of an organic soluble acid proceeds rather slowly but can be significantly accelerated in the presence of cobalt porphyrins as catalysts. ${ }^{30-32}$ In bulk phases, the reaction proceeds by a PCET reaction with electron transfer from $\mathrm{Fc}$ to $\mathrm{O}_{2}$ and proton transfer from an organic soluble acid to $\mathrm{O}_{2}$. The catalysis originates from the formation of a superoxide-like intermediate, in which an electron partially delocalizes from the cobalt porphyrin to $\mathrm{O}_{2}$. In the present biphasic system, the proton-coupled oxygen reduction by Fc occurs also interfacially as observed by voltammetry, with protons from the aqueous phase and electron donors from DCE. The overall reaction can be expressed as:

$$
2 \mathrm{Fc}_{(\mathrm{o})}+\mathrm{O}_{2(\mathrm{~g})}+2 \mathrm{H}_{(\mathrm{w})}^{+} \stackrel{\mathrm{CoP}}{\longrightarrow} 2 \mathrm{Fc}_{(\mathrm{o})}^{+}+\mathrm{H}_{2} \mathrm{O}_{2(\mathrm{w})}
$$

and/or

$$
4 \mathrm{Fc}_{(\mathrm{o})}+\mathrm{O}_{2(\mathrm{~g})}+4 \mathrm{H}_{(\mathrm{w})}^{+} \stackrel{\mathrm{CoP}}{\longrightarrow} 4 \mathrm{Fc}_{(\mathrm{o})}^{+}+2 \mathrm{H}_{2} \mathrm{O}_{(\mathrm{w})}
$$

They correspond to a two-electron reduction and a fourelectron reduction pathway, respectively. The oxygen concentration in the air-saturated DCE is $1.39 \mathrm{mM},{ }^{33}$ and the consumption of oxygen in DCE is accompanied by the oxygen partition at the water-DCE and air-water interfaces. ${ }^{34,35}$ It is also important to remember that current signals at ITIES are solely the result of the transfer of charges (ions or electrons) across the interface. In other words, the irreversible current wave experimentally observed at positive potentials represents essentially a proton flux controlled directly by the electrochemical polarization. Another point worthy of stressing is that in the two-phase experiment with $\mathrm{TB}^{-}$as a common ion the Galvani distribution potential resulting from the partition of all ions is very positive,

(30) Fukuzumi, S.; Mochizuki, S.; Tanaka, T. Chem. Lett. 1989, 27-30.

(31) Fukuzumi, S.; Mochizuki, S.; Tanaka, T. Inorg. Chem. 1989, 28, 245965.

(32) Fukuzumi, S.; Okamoto, K.; Gros, C. P.; Guilard, R. J. Am. Chem. Soc. 2004, 126, 10441-10449.

(33) Luehring, P.; Schumpe, A. J. Chem. Eng. Data 1989, 34, $250-2$.

(34) Barker, A. L.; Macpherson, J. V.; Slevin, C. J.; Unwin, P. R. J.Phvs. Chem. B 1998, 102, 1586-1598.

(35) Slevin, C. J.; Ryley, S.; Walton, D. J.; Unwin, P. R. Langmuir 1998, 14, 5331-5334.
Table 3. Calculated Equilibrium Concentrations after Contact with $5 \mathrm{mM}$ TMATB in DCE with $10 \mathrm{mM} \mathrm{HCl}$ and $5 \mathrm{mM} \mathrm{TMACl}$ in Water $^{a}$

\begin{tabular}{lccclc}
\hline & $C_{\mathrm{Fc}}+/ \mathrm{mM}$ & $C_{\mathrm{H}}+/ \mathrm{mM}$ & $C_{\mathrm{TMA}}+/ \mathrm{mM}$ & \multicolumn{1}{c}{$C_{\mathrm{TB}}-/ \mathrm{mM}$} & $c_{\mathrm{Cl}}-/ \mathrm{mM}$ \\
\hline water & 0 & 10.00 & 5.00 & $2.58 \times 10^{-8}$ & 15.00 \\
DCE & 0 & $2.53 \times 10^{-6}$ & 5.00 & 5.00 & $3.21 \times 10^{-11}$
\end{tabular}

${ }^{a}$ The Galvani potential difference across the water-DCE interface calculated is approximately $0.16 \mathrm{~V}$.

Table 4. List of the Standard Redox Potentials of Various Redox Couples

\begin{tabular}{llc}
\hline \multicolumn{1}{c}{ redox reaction } & medium & {$\left[E_{\mathrm{O} / \mathrm{R}}^{0}\right]_{\mathrm{SHE}}^{\alpha}(\alpha=\mathrm{w}, \mathrm{o}) / \mathrm{V}$} \\
\hline $\mathrm{CoP}^{+}+e^{-} \rightarrow \mathrm{CoP}$ & $\mathrm{DCE}$ & $1.15^{a}$ \\
$\mathrm{Fc}^{+}+e^{-} \rightarrow \mathrm{Fc}$ & $\mathrm{DCE}$ & $0.64^{b}$ \\
$\mathrm{DFc}^{+}+e^{-} \rightarrow \mathrm{DFc}$ & DCE & $0.55^{b}$ \\
$\mathrm{FcCA}^{+}+e^{-} \rightarrow \mathrm{FcCA}$ & DCE & $0.96^{c}$ \\
$\mathrm{O}_{2}+2 \mathrm{H}^{+}+2 e^{-} \rightarrow \mathrm{H}_{2} \mathrm{O}_{2}$ & DCE & $1.166^{d}$ \\
$\mathrm{O}_{2}+4 \mathrm{H}^{+}+4 e^{-} \rightarrow 2 \mathrm{H}_{2} \mathrm{O}$ & DCE & $1.749^{d}$ \\
$\mathrm{O}_{2}+2 \mathrm{H}^{+}+2 e^{-} \rightarrow \mathrm{H}_{2} \mathrm{O}_{2}$ & water & $0.695^{e}$ \\
$\mathrm{O}_{2}+4 \mathrm{H}^{+}+4 e^{-} \rightarrow 2 \mathrm{H}_{2} \mathrm{O}$ & water & $1.229^{e}$
\end{tabular}

${ }^{a}$ Measured by cyclic voltammetry using a Pt electrode $25 \mu \mathrm{m}$ in diameter and a silver wire as the working and quasi-reference electrode, $5 \mathrm{mM}$ BATB as the supporting electrolyte. ${ }^{b}$ From reference $36 .{ }^{c}$ From reference 37. ${ }^{d}$ Calculated from a thermodynamic cycle as shown in the Supporting Information. ${ }^{e}$ From reference 38.

Scheme 4. Interfacial PCET Mechanism

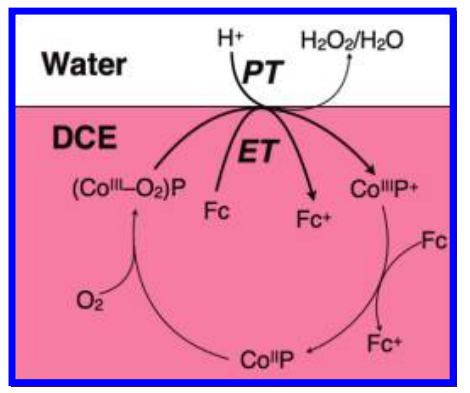

ensuring that $\mathrm{Fc}^{+}$produced during the reaction remains in the organic phase and does not transfer to the aqueous one where it is not chemically stable. Indeed, after the two-phase reaction the Galvani potential difference across the water-DCE interface decreased to approximately $0.27 \mathrm{~V}$ as shown in Table 2, which nevertheless is still positive enough to confine $\mathrm{Fc}^{+}$in DCE.

Thermodynamic Analysis. A three-step reaction mechanism is proposed as illustrated in Scheme 4, in which the PT and ET are coupled at the water-DCE interface leading to the irreversible current observed by voltammetry. The PCET is accompanied by the regeneration of $\mathrm{CoP}$ by $\mathrm{Fc}$ and the oxygen coordination with $\mathrm{CoP}$. These steps can be expressed as follows:

(36) Eugster, N.; Fermin, D. J.; Girault, H. H. J. Phys. Chem. B 2002, $106,3428-3433$.

(37) Measured by cyclic voltammetry using a Pt electrode $25 \mu \mathrm{m}$ in diameter and a silver wire as the working and quasi-reference electrode, $5 \mathrm{mM}$ BATB as the supporting electrolyte.

(38) Girault, H. H. Analytical and Physical Electrochemistry; EPFL Press: Lausanne, 2004. 


$$
2 e:\left(\mathrm{Co}^{\mathrm{III}}-\mathrm{O}_{2}\right) \mathrm{P}_{(\mathrm{o})}+\mathrm{Fc}_{(\mathrm{o})}+2 \mathrm{H}_{(\mathrm{w})}^{+} \rightarrow \mathrm{Co}^{\mathrm{III}} \mathrm{P}_{(\mathrm{o})}^{+}+\underset{\mathrm{H}_{2} \mathrm{O}_{2(\mathrm{w})}}{\mathrm{Fc}_{(\mathrm{o})}^{+}+}
$$

or

$$
\begin{aligned}
& 4 e: \mathrm{P}\left(\mathrm{Co}^{\mathrm{III}}-\mathrm{O}_{2}-\mathrm{Co}^{\mathrm{III}}\right) \mathrm{P}_{(\mathrm{o})}+2 \mathrm{Fc}_{(\mathrm{o})}+4 \mathrm{H}_{(\mathrm{w})}^{+} \rightarrow 2 \mathrm{Co}^{\mathrm{III}} \mathrm{P}_{(\mathrm{o})}^{+}+ \\
& 2 \mathrm{Fc}_{(\mathrm{o})}^{+}+2 \mathrm{H}_{2} \mathrm{O}_{(\mathrm{w})} \\
& \mathrm{Co}^{\mathrm{III}} \mathrm{P}_{(\mathrm{o})}^{+}+\mathrm{Fc}_{(\mathrm{o})} \rightarrow \mathrm{Co}^{\mathrm{II}} \mathrm{P}_{(\mathrm{o})}+\mathrm{Fc}_{(\mathrm{o})}^{+} \\
& 2 e: \mathrm{Co}^{\mathrm{II}} \mathrm{P}_{(\mathrm{o})}+\mathrm{O}_{2(\mathrm{o})} \rightarrow\left(\mathrm{Co}^{\mathrm{III}}-\mathrm{O}_{2}\right) \mathrm{P}_{(\mathrm{o})} \\
& 4 e: 2 \mathrm{Co}^{\mathrm{II}} \mathrm{P}_{(\mathrm{o})}+\mathrm{O}_{2(\mathrm{o})} \rightarrow \mathrm{P}\left(\mathrm{Co}^{\mathrm{III}}-\mathrm{O}_{2}-\mathrm{Co}^{\mathrm{III}}\right) \mathrm{P}_{(\mathrm{o})}
\end{aligned}
$$

In the case of a two-electron reduction pathway (eq 3a), the Gibbs energy of the PCET reaction at equilibrium is:

$$
\Delta G=\tilde{\mu}_{\mathrm{CoP}^{+}}^{\mathrm{o}}+\tilde{\mu}_{\mathrm{Fc}^{+}}^{\mathrm{o}}+\mu_{\mathrm{H}_{2} \mathrm{O}_{2}}^{\mathrm{w}}-\mu_{\left(\mathrm{Co}-\mathrm{O}_{2}\right) \mathrm{P}}^{\mathrm{o}}-\mu_{\mathrm{Fc}}^{\mathrm{o}}-2 \tilde{\mu}_{\mathrm{H}^{+}}^{\mathrm{w}}=0
$$

Similarly, that of eq $5 \mathrm{a}$ is:

$$
\Delta G=\mu_{\left(\mathrm{Co}_{0}-\mathrm{O}_{2}\right) \mathrm{P}}^{\mathrm{o}}-\mu_{\mathrm{CoP}}^{\mathrm{o}}-\mu_{\mathrm{O}_{2}}^{\mathrm{g}}=0
$$

where $\tilde{\mu}_{i}^{\alpha}$ and $\mu_{i}^{\alpha}$ represent the electrochemical potential and chemical potential of species $i$ in their respective phases $(\mathrm{o}, \mathrm{w}$, or g). By combining eqs 6 and 7, developing and introducing the standard redox potentials, we have:

$$
\begin{aligned}
& \Delta_{\mathrm{o}}^{\mathrm{w}} \phi_{2 \mathrm{et}}=\Delta_{\mathrm{o}}^{\mathrm{w}} \phi_{2 \mathrm{et}}^{0} \frac{R T \ln 10}{F} \mathrm{pH}+ \\
& \frac{R T}{2 F} \ln \left[\left(\frac{a_{\mathrm{Fc}^{+}}^{\mathrm{o}}}{a_{\mathrm{Fc}}^{\mathrm{o}}}\right)\left(\frac{a_{\mathrm{COP}^{+}}^{\mathrm{o}}}{a_{\mathrm{CoP}}^{\mathrm{o}}}\right)\left(\frac{p^{0}}{f_{\mathrm{O}_{2}}}\right) a_{\mathrm{H}_{2} \mathrm{O}_{2}}^{\mathrm{w}}\right]
\end{aligned}
$$

where $a_{i}^{\alpha}$ represents the activity of species $i . f_{\mathrm{O}_{2}}$ and $p^{0}$ are the fugacity of oxygen and the standard pressure. $\Delta_{0}^{\mathrm{w}} \phi_{2 \mathrm{et}}^{0}$ represents the standard potential for the two-electron interfacial PCET reaction catalyzed by $\mathrm{CoP}$ given by

$$
\Delta_{\mathrm{o}}^{\mathrm{w}} \phi_{2 \mathrm{et}}^{0}=\frac{1}{2}\left[E_{\mathrm{CoP}+/ \mathrm{CoP}}^{0}\right]_{\mathrm{SHE}}^{\mathrm{o}}+\frac{1}{2}\left[E_{\mathrm{Fc}+/ \mathrm{Fc}}^{0}\right]_{\mathrm{SHE}}^{\mathrm{o}}-\left[E_{\mathrm{O}_{2} / \mathrm{H}_{2} \mathrm{O}_{2}}^{0}\right]_{\mathrm{SHE}}^{\mathrm{w}}
$$

where $\left[E_{\mathrm{COP}^{+} / \mathrm{CoP}}^{0}\right]_{\mathrm{SHE}}^{0},\left[E_{\mathrm{Fc}}^{0} / / \mathrm{Fc}\right]_{\mathrm{SHE}}^{0}$, and $\left[E_{\mathrm{O}_{2} / \mathrm{H}_{2} \mathrm{O}_{2}}^{0}\right]_{\mathrm{SHE}}^{\mathrm{W}}$ denote the standard redox potentials of the $\mathrm{CoP}^{+} / \mathrm{CoP}$ and $\mathrm{Fc}^{+} / \mathrm{Fc}$ couples in DCE and $\mathrm{O}_{2} / \mathrm{H}_{2} \mathrm{O}_{2}$ couple in water, respectively, all with respect to the aqueous standard hydrogen electrode (SHE).

In the same way, the redox potential for the four-electron interfacial PCET reaction catalyzed by $\mathrm{CoP}$ (eq 3b) can be derived as follows:

$$
\begin{aligned}
\Delta_{\mathrm{o}}^{\mathrm{w}} \phi_{4 \mathrm{et}}=\Delta_{\mathrm{o}}^{\mathrm{w}} \phi_{4 \mathrm{et}}^{0}+ & \frac{R T \ln 10}{F} \mathrm{pH}+ \\
& \frac{R T}{4 F} \ln \left[\left(\frac{a_{\mathrm{Fe}^{+}}^{\mathrm{o}}}{a_{\mathrm{Fc}}^{\mathrm{o}}}\right)^{2}\left(\frac{a_{\mathrm{COP}^{+}}^{\mathrm{o}}}{a_{\mathrm{CoP}}^{\mathrm{o}}}\right)^{2}\left(\frac{p^{0}}{f_{\mathrm{O}_{2}}}\right)\left(a_{\mathrm{H}_{2} \mathrm{O}}^{\mathrm{w}}\right)^{2}\right]
\end{aligned}
$$

with the standard potential given by

$$
\Delta_{\mathrm{o}}^{\mathrm{w}} \phi_{4 \mathrm{et}}^{0}=\frac{1}{2}\left[E_{\mathrm{Co}+/ \mathrm{CoP}}^{0}\right]_{\mathrm{SHE}}^{\mathrm{o}}+\frac{1}{2}\left[E_{\mathrm{Fc}+/ \mathrm{Fc}}^{0}\right]_{\mathrm{SHE}}^{\mathrm{o}}-\left[E_{\mathrm{O}_{2} / \mathrm{H}_{2} \mathrm{O}}^{0}\right]_{\mathrm{SHE}}^{\mathrm{w}}
$$

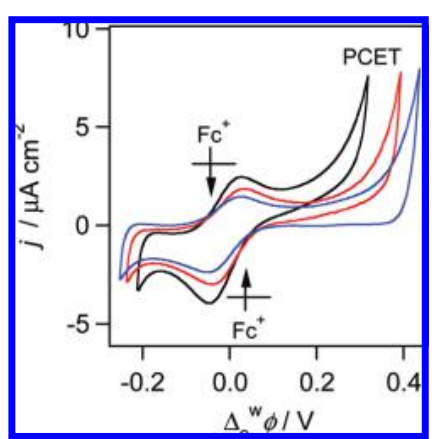

Figure 4. Cyclic voltammetry at a water-DCE interface with the cell illustrated in Scheme 3 in the presence of $5 \mathrm{mM} \mathrm{Fc}$ and $50 \mu \mathrm{M} \mathrm{CoP}(x=$ 50 and $y=5$ ) at $\mathrm{pH} 1$ (black), $\mathrm{pH} 2$ (red), and $\mathrm{pH} 3$ (blue). The curves show that ferrocenium is stable in the aqueous phase on the time scale of a scan.

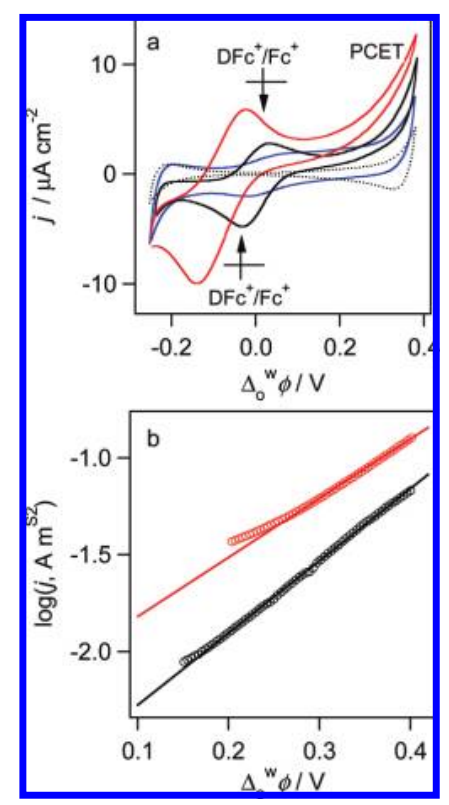

Figure 5. (a) Cyclic voltammetry at a water-DCE interface obtained with the cell illustrated in Scheme 3 in the presence of $50 \mu \mathrm{M} \mathrm{CoP}$ and different electron donors ( $x=50$ and $y=5$ ): Fc (black), DFc (red), and FcCA (blue). The dotted curve represents the background CV $(x=0$ and $y=0)$. (b) Tafel plots the background-subtracted catalytic current in the forward scan for Fc (black) and DFc (red).

Equations 8 and 10 represent the Nernst equations for the two- and four-electron interfacial PCET reaction, both of which predict a $\mathrm{pH}$ dependence of the voltammetric signal. Indeed, the observed current shifts with $\mathrm{pH}$ by around $60 \mathrm{mV} / \mathrm{pH}$, as shown in Figure 4, and as predicted by eqs 8 and 10. The Nernst equations also predict a dependence on the value of the standard redox potential of the organic electron donor. When $\mathrm{Fc}$ is replaced either by a stronger electron donor, $\mathrm{DFc}$, or by a weaker one, $\mathrm{FcCA}$, the onset potential of the irreversible current shifts to negative and positive potentials, respectively. $\mathrm{Fc}, \mathrm{DFc}$, and FcCA have standard redox potential values of $0.64,0.55,{ }^{36}$ and $0.94 \mathrm{~V} ;{ }^{37}$ therefore, the shift observed from the voltammetric data of Figure 5a corroborates the predictions of eqs 8 and 10. According to these two equations, a shift of $45 \mathrm{mV}$ is expected for $\mathrm{Fc}$ and $\mathrm{DFc}$, which can be easily observed with a Tafel plot (Figure 5b). The shift of the Tafel plot undoubtedly shows that the electron donor takes part in the interfacial PCET reaction. The standard redox potentials of a two-electron reduction reaction for $\mathrm{Fc}$ and $\mathrm{DFc}$ are equal to 0.20 and $0.15 \mathrm{~V}$, while 


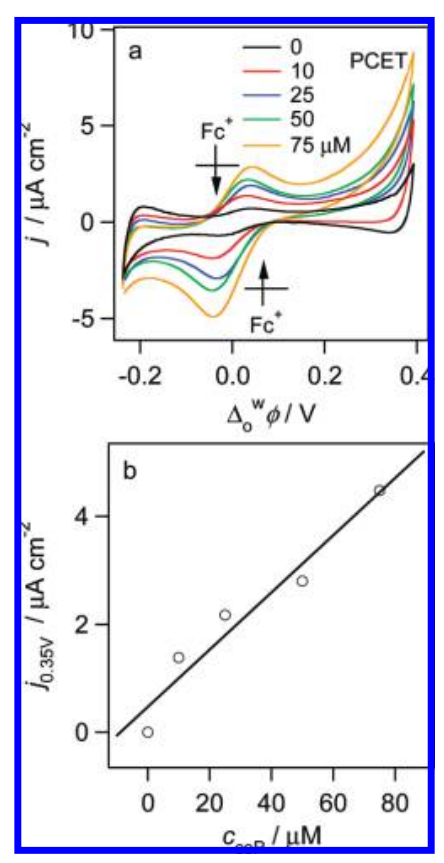

Figure 6. (a) Cyclic voltammetry at a water-DCE interface obtained with the cell illustrated in Scheme 3 in the presence of $5 \mathrm{mM} \mathrm{Fc}(y=5)$ and various concentrations of $\mathrm{CoP}$. (b) Linear dependence of the irreversible current at $0.35 \mathrm{~V}$ on the $\mathrm{CoP}$ concentration.

those of a four-electron reduction reaction are -0.34 and -0.38 $\mathrm{V}$, as calculated with eqs 9 and 11 . This might suggest that the catalytic current is due to a two-electron reduction of $\mathrm{O}_{2}$, because experimentally the catalytic current was only observed at positive potentials.

Kinetic Analysis. The irreversible current depends on the oxygen concentration (Figure 1), and it is also directly proportional to the CoP concentration in the range $0-0.1 \mathrm{mM}$ when $\mathrm{O}_{2}, \mathrm{Fc}$, and protons are in excess, as shown in a and b of Figure 6. Additionally, Figure 7 a shows that the current is directly proportional to the $\mathrm{Fc}$ concentration in the range $0.2-1 \mathrm{mM}$, i.e. when it is lower than the oxygen concentration. Above 1 $\mathrm{mM}$, the current becomes independent of the electron donor concentration as shown in Figure 7b. As the proton concentration is always in excess, the voltammetric data indicates that the rate-limiting step depends on the concentration ratio of the different reactants. In the presence of an excess of aqueous protons and organic electron donor, the catalytic cycle rate is limited by the potential-dependent PCET step between $\left(\mathrm{Co}^{\mathrm{III}}-\mathrm{O}_{2}\right) \mathrm{P}, \mathrm{H}^{+}$, and Fc. Indeed, the other steps such as the reduction of $\mathrm{Co}^{\mathrm{III}} \mathrm{P}^{+}$and the formation of $\left(\mathrm{Co}^{\mathrm{III}}-\mathrm{O}_{2}\right) \mathrm{P}$ are bulk reactions and therefore potential independent.

\section{Conclusions}

This work shows that voltammetry at soft interfaces is a very powerful tool to study proton-coupled electron transfer reactions of biological interest such as the interfacial reduction of oxygen catalyzed by a metalloporphyrin, e.g. Co(II) porphine. As in biosystems, the reactants can be phase separated with the protons

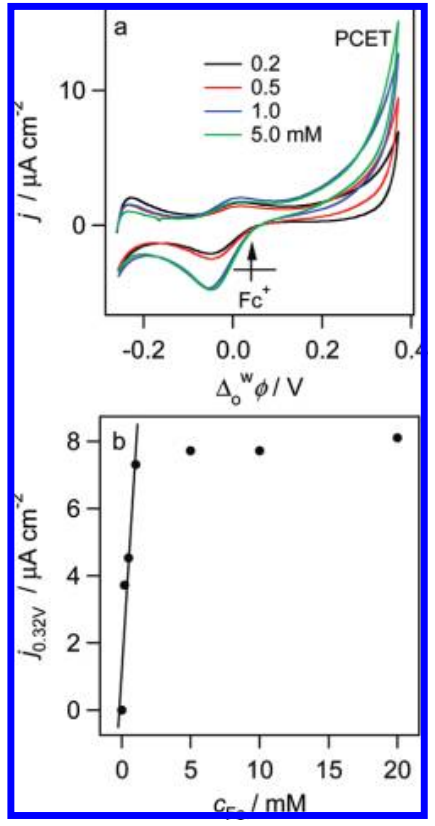

Figure 7. (a) Cyclic voltammetry at a water-DCE interface obtained with the cell illustrated in Scheme 3 in the presence of $50 \mu \mathrm{M} \mathrm{CoP}(x=50)$ and various concentration of Fc. The curves represent the first scans. (b) Dependence of the irreversible current at $0.32 \mathrm{~V}$ on the Fc concentration. The straight line corresponds to a linear fitting in the lower concentration range.

in the aqueous phase and the electron donors in the organic phase. In the present model system, we have reacted an oxygen carrier catalyst (namely cobalt porphine, aqueous protons and lipophilic electron donors) and shown that voltammetry can be efficiently used to probe the interfacial reaction. To the best of our knowledge this work is the first voltammetric study of an electrocatalytic reaction at a soft interface, where the rate of the catalytic reaction is controlled by the interfacial polarization, i.e. by the applied potential difference. This investigation opens the way for studying synthetic catalysts able to carry out the four-electron reduction of oxygen to water.

Acknowledgment. This work was supported by EPFL, the Swiss National Science Foundation (FNRS 200020-116588), CNRS, Grant Agency of the Czech Republic (No. 203/07/1257), and European Cost Action D36/007/06 and CNRS. I.H. and M.E. also gratefully acknowledge the Scientific and Technological Research Council of Turkey (TUBITAK) under the 2212-PhD Scholarship Program.

Supporting Information Available: Synthetic details of CoP, calculations of the Galvani potential difference across the liquid-liquid interface, calculations of the standard redox potential in the organic phase, two-phase reaction and liquidliquid electrochemistry data. This material is available free of charge via the Internet at http://pubs.acs.org.

JA904569P 